\title{
IN-PLACE ANALYSIS OF OFFSHORE JACKET PLATFORM FOR DIFFERENT WAVE DIRECTIONS
}

\author{
Mirza Aamir Baig ${ }^{* 1}$ 价, Umer Maqbool 2 \\ *1, 2 Department of Civil Engineering, Alfalah University, India
}

DOI: https://doi.org/10.29121/IJOEST.v4.i5.2020.108

Article Type: Research Article

Article Citation: Mirza Aamir Baig, and Umer Maqbool. (2020). INPLACE ANALYSIS OF OFFSHORE JACKET PLATFORM FOR DIFFERENT WAVE DIRECTIONS. International Journal of Engineering Science Technologies, 4(5), 16-25. https://doi.org/10.29121/IJOEST.v 4.i5.2020.108

Received Date: 26 August 2020

Accepted Date: 23 September 2020

Keywords:

Dynamic Response

Regular and Irregular Wave

Pm Spectrum

Morission's Equation

Airy's Teory

Deterministic Wave

Random Wave

Mode Shape

Frequency

\section{ABSTRACT}

Offshore jacket platforms are subjected to variety of forces during their life period. To resists all kinds of forces, the structural elements should be designed properly to have safety and economy. In order to fulfil this purpose, the structure should be analyzed with great care.

As the improvement of oil and gas moves into more profound water, in any case, taller stages with longer periods are fabricated that react all the more powerfully to extraordinary waves. Expectation of the dynamic reaction of such structures in extraordinary ocean states is in this way an essential plan thought. Standard waves have all their vitality lumped at a couple of particular frequencies and can, in this manner, cause wrong powerful enhancements, particularly if these frequencies happen to be near the regular frequencies of the structure. In any case, waves in the ocean are exceptionally sporadic and can be best depicted as directional range, which indicates the appropriation of wave vitality as for recurrence and heading, and is most appropriate for the examination of structure in recurrence space technique. For this situation the nonlinear drag is linearized and utilized in the Morison's condition. This guess is proper for the littler, operational sort waves considered in weariness counts, in light of the fact that the powers because of these waves are overwhelmed by the direct idleness part. Various kinds of investigations related with the coat stage ought to be performed to figure the reaction of the structure and measurement the components of the structure. Here an endeavor has been made to complete various examinations to comprehend the dynamic conduct of coat stages subject to different stacking conditions in various ecological conditions. Coat set up investigation was performed, both static and dynamic hypothetically fixed base stage.

With the ongoing imaginative thoughts of investigation utilizing programming, it is presently simpler for the seaward architects to do disentangled and sensible assessment of the static operational and extreme point of confinement state qualities of format or coat stages, which are exposed to different ecological conditions. The essential auxiliary parts of coat type seaward structures including topsides, coat, heaps and the encompassing soil are viewed as utilizing SACS programming various types of investigations identified with coat stage according to API code prerequisite.

\section{INTRODUCTION}

Offshore platforms have numerous utilizations including oil investigation and generation, route, deliver stacking and emptying, and to help scaffolds and thoroughfares. Seaward oil generation is one of the most unmistakable of these applications and speaks to a huge test to the plan engineer. These seaward structures must

(C) 2020 The Author(s). This is an open access article distributed under the terms of the Creative Commons Attribution License, which permits unrestricted use, distribution, and reproduction in any medium, provided the original author and source are credited. 
In-place Analysis of Offshore Jacket Platform for Different Wave Directions

capacity securely for plan lifetimes of twenty years or more and are liable to exceptionally brutal marine conditions. Some significant plan contemplations are pinnacle burdens made by tropical storm wind and waves, weakness burdens created by waves over the stage lifetime and the movement of the stage. The stages are once in a while exposed to solid flows which make stacks on the securing framework and can instigate vortex shedding. Seaward stages are tremendous steel or solid structures utilized for the investigation and extraction of oil and gas from the world's hull. Seaward structures are intended for establishment in the vast ocean, lakes, inlets, and so forth., numerous kilometers from shorelines. These structures might be made of steel, strengthened cement or a blend of both. The seaward oil and gas stages are commonly made of different evaluations of steel, from gentle steel to highquality steel, albeit a portion of the more established structures were made of fortified cement.

The oil and gas are isolated at the stage and shipped through pipelines or by tankers to shore.

The Increasing interest for vitality has driven people to look for oil and gas past its property bolted properties. Uncovering for oil in seaward regions has started for quite a long while. This industry depends on seaward structures as a component of their reality. Steel stages are one of the most widely recognized kinds of auxiliary frameworks at present utilized for oil abuse purposes. These structures are commonly intended to oppose ecological loads in particular, utilitarian loads and loads because of waves, flows, wind just as seismic tremor excitations.

Stage structures are generally used for different purposes including seaward boring, preparing and backing of seaward activities. Coat type structures are alluring in generally shallow water locales. A coat is a supporting structure for deck offices balanced out by leg heaps through the seabed.

\section{LOADS CONSIDERED FOR OFFSHORE PLATFORMS}

Loads on offshore structures are gravity loads and environmental loads. Gravity loads are emerging from dead weight of structure and offices either lasting or transitory. Seismic loads are emerging from gravity loads and could be a determined sort. Environmental loads play a major part overseeing the plan of seaward structures. Sometime recently beginning the plan of any structure, forecast of natural loads precisely is critical. Different natural loads acting on the seaward stage is recorded underneath.

1) Gravity Loads

- Structural Dead Loads, Facility Dead Loads, Fluid Loads, Live Loads and Drilling Loads

2) Environmental loads

- Wind Loads, Wave Loads, Current Loads, Buoyancy Loads and Ice Loads Mud Loads

3) Seismic Loads

\section{MORISON'S EQUATION}

Wave and current loading can be calculated by Morison equation

$\mathrm{FT}=1 / 2 \mathrm{CD} \rho \mathrm{WDV}|\mathrm{V}|+\Pi \mathrm{D} 2 / 4 \mathrm{CM}+\rho \mathrm{Wa}$

Where FT is the total force, $\rho \mathrm{w}$ is the density of water, CD and CM are the drag and inertia coefficients respectively, $\mathrm{D}$ is the diameter of the member including marine growth, $\mathrm{V}$ is the velocity and a is the acceleration. The first term in the equation is drag component (FD) and the second term is the inertia component (FI). This can be expressed as

$$
\mathrm{FT}=\mathrm{FD}+\mathrm{FI}
$$

\section{SELECTION OF WAVE THEORY}

The computation of wave kinematics such as velocity and acceleration involve the equations from wave theory. There are various kinds of solutions available depending on the accuracy required, and parameters involved in the computation. The various wave theories are listed below: 
- Linear / Airy Wave Theory

- Stokes Wave Theory

- Stream Function Wave Theory

- Cnoidal Wave Theory

Depending on the area such as profound water or shallow water and related wave parameters, a appropriate wave hypothesis might be chosen for utilize. API RP2A prescribes to utilize a Chart for such choice based on d/gT2 and H/gT2 as the X and Y hub. The wave speculations talked about over are for non-breaking waves. For $\mathrm{H} / \mathrm{h}>0.78$, these hypotheses are not pertinent as the waves tend to break. In such circumstance, experimental conditions might be utilized to calculate the breaking wave powers on the structures.

\section{MODEL AND MODEL PARAMETERS CONSIDERED FOR ANALYSIS}

The geometry of the jacket structure used in this study is described in the following section. Meanwhile the elements used to model the jacket structure are also discussed. Fig 1 show the structure model developed using SACS.

The structure analyzed in this study is basically a four-leg steel offshore jacket installed in water depth of $80 \mathrm{~m}$.

\subsection{SEA-STATE DATA}

Sea state is the general condition of the free space on a large body of water with respect to wind waves and swells. A swell is the formation of long wave length surface waves. Swells are far more stable in their directions and frequency than normal wind waves, having often travelled long distances since their formation by tropical storms or other wind systems.

In engineering applications, the sea state is often characterized by significant wave height and period and often by wave spectrum.

Six different sea states are considered for static and dynamic wave response analysis namely:

Operational condition in 0, 45, 90 degrees and storm condition in 0, 45, 90 degrees.

\subsection{OPERATIONAL CONDITION}

Wind Speed $=25.7(\mathrm{~m} / \mathrm{s})$

Wave Height $=6.1 \mathrm{~m}$

Period $=13.0 \mathrm{sec}$

Current Speed $=0.305, .610 \mathrm{~m} / \mathrm{sec}$

\subsection{STORM CONDITION}

Wind Speed $=77.2$

Wave Height $=12.19 \mathrm{~m}$,

Period $=13.0 \mathrm{sec}$

Current Speed =1.5, $3.5 \mathrm{~m} / \mathrm{sec}$

Stoke's wave theory of order 5 is used for the analyses. Coefficient of drag and inertia are taken as 0.6 and 1.2.

\subsection{LOAD COMBINATION}

Table 2: Load Combinations

\begin{tabular}{|c|c|}
\hline Load & Combination \\
\hline P000 & $6.1 \mathrm{~m}$ Wave $+0.305 \mathrm{~m} / \mathrm{sec}$ Current + Buoyancy +Marine Growth+ Wind \\
\hline P045 & $6.1 \mathrm{~m}$ Wave $+0.305 \mathrm{~m} / \mathrm{sec}$ Current + Buoyancy +Marine Growth+ Wind \\
\hline P090 & $6.1 \mathrm{~m}$ Wave $+0.305 \mathrm{~m} / \mathrm{sec}$ Current + Buoyancy +Marine Growth+ Wind \\
\hline
\end{tabular}


In-place Analysis of Offshore Jacket Platform for Different Wave Directions

\begin{tabular}{|c|c|}
\hline S000 & $12.19 \mathrm{~m}$ Wave $+0.305 \mathrm{~m} / \mathrm{sec}$ Current + Buoyancy +Marine Growth + Wind \\
\hline S045 & $12.19 \mathrm{~m}$ Wave $+0.305 \mathrm{~m} / \mathrm{sec}$ Current + Buoyancy +Marine Growth+ Wind \\
\hline S090 & $12.19 \mathrm{~m}$ Wave $+0.305 \mathrm{~m} / \mathrm{sec}$ Current + Buoyancy +Marine Growth+ Wind \\
\hline OPR1 & DL+LL+EQP.MISC+P000 \\
\hline OPR2 & DL+LL+EQP.+MISC+P045 \\
\hline OPR3 & DL+LL+EQP.+MISC+P090 \\
\hline STM1 & DL+0.75LL+EQP.+MISC+S000 \\
\hline STM2 & DL+0.75LL+EQP.+MISC+S045 \\
\hline STM3 & DL+0.75LL+EQP.+MISC+S090 \\
\hline
\end{tabular}

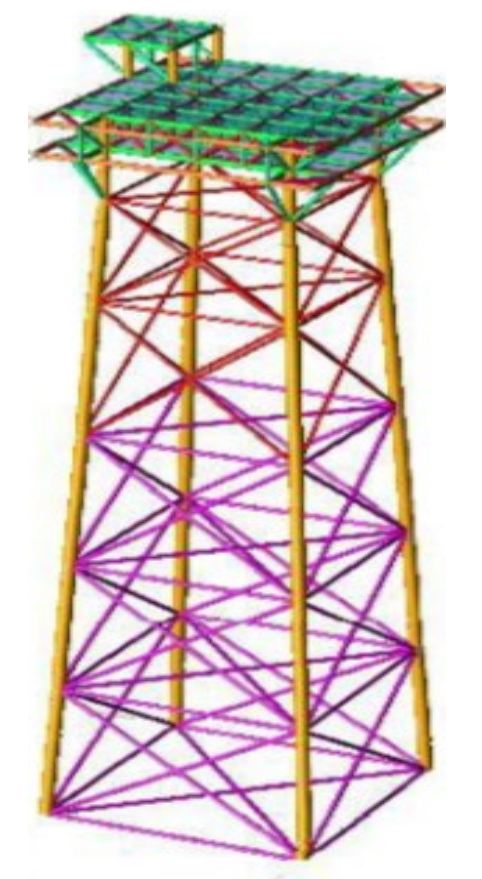

Figure 1: Offshore Jacket Model

\section{RESULTS AND DISCUSSION}

Sea state Loads for Wave Passing Through Structure was acted upon the structure and analysis results were found using SACS. The maximum and minimum values of overturning moment, base shear etc. were calculated as tabulated below in Table 2. The structure is analyzed for different Wave theories. From the results provided in the table the Base Shear and Overturning Moment increases with increase in wave height. The maximum overturning moment and Base Shear are in load case S090.

\subsection{STATIC ANALYSIS}

Table 2: Base Shear and Overturning Moment for different Load Combination

\begin{tabular}{|c|c|c|c|c|}
\hline \multirow{2}{*}{ Load Condition } & \multicolumn{2}{|c|}{ Base shear } & \multicolumn{2}{c|}{ Overturning moment } \\
\cline { 2 - 5 } & FX (kN) & FZ (KN) & MX (kN-m) & MZ (kN-m) \\
\hline OPR1 & 1085.87 & -67770.3 & -36127.5 & -457.4 \\
\hline OPR2 & 762.18 & -67779.1 & -91090.5 & -610.1 \\
\hline OPR3 & 0 & -67772.9 & -114132.2 & -405.4 \\
\hline STM1 & 5366.17 & -71746.2 & -48647.6 & -4116.2 \\
\hline STM2 & 3771.99 & -71755.6 & -388842.7 & -5489.9 \\
\hline
\end{tabular}


Mirza Aamir Baig, and Umer Maqbool

\begin{tabular}{|c|c|c|c|c|}
\hline STM3 & 0 & -71769.1 & -531582.7 & -3647.7 \\
\hline
\end{tabular}

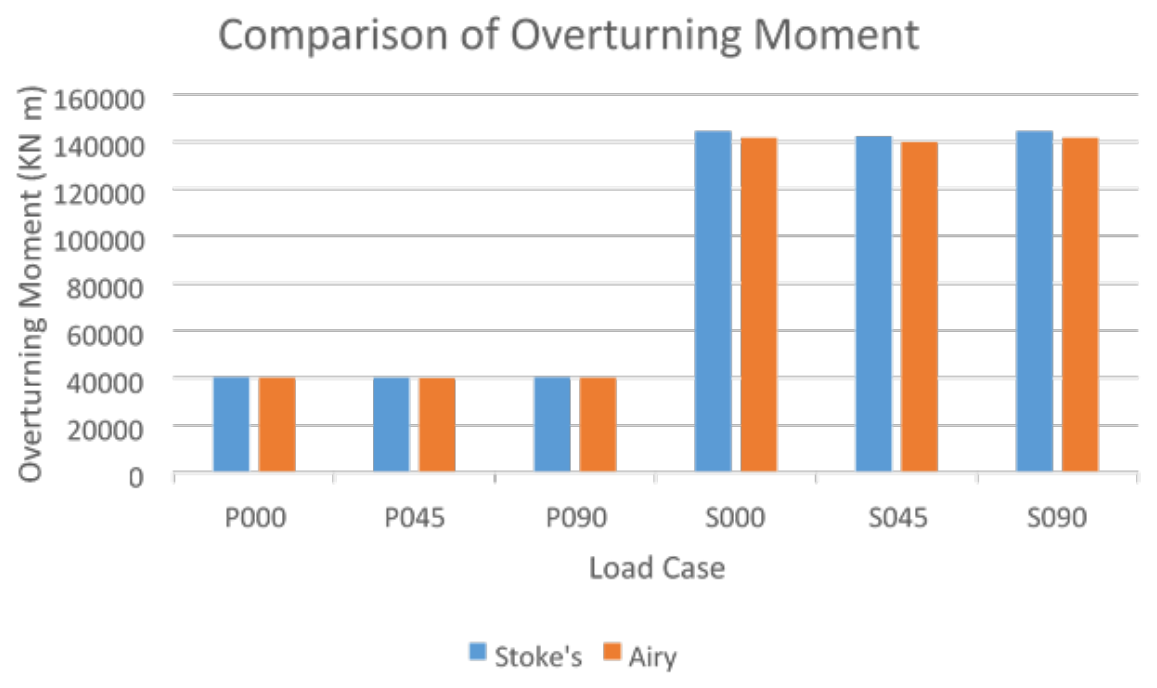

Figure 2: Overturning Moment from different wave theory.

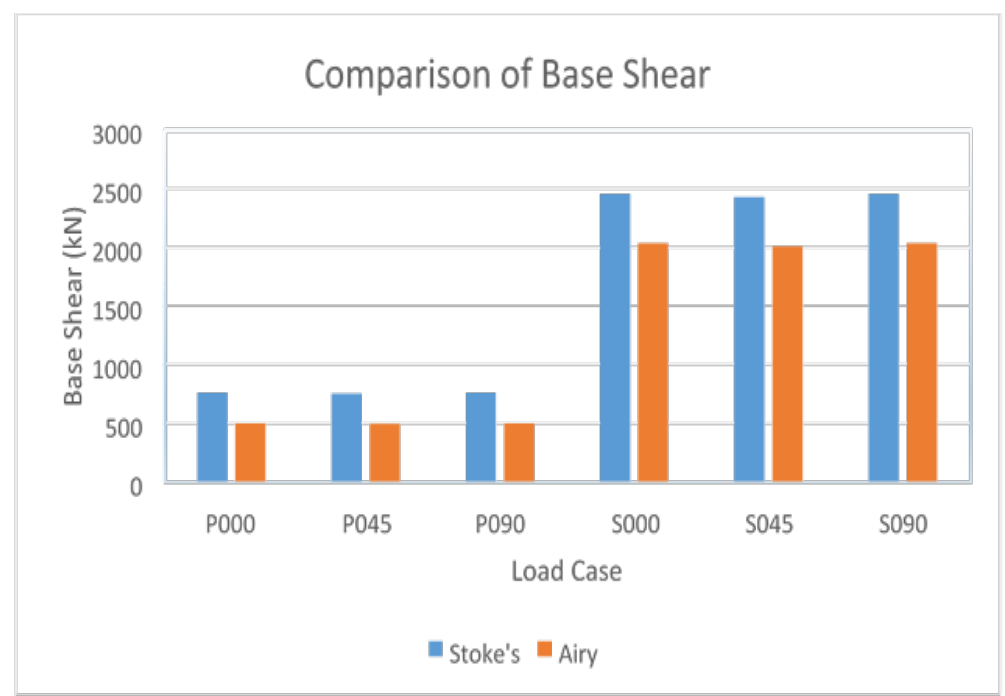

Figure 3: Base Shear from different wave theory.

\subsection{DYNAMIC ANALYSIS}

Table 3: Frequencies and Generalized Mass

\begin{tabular}{|c|c|c|c|c|}
\hline \multicolumn{5}{|c|}{ Frequencies and Generalized Mass } \\
\hline Mode & Freq. (CPS) & Gen. Mass & Eigen Value & Period (Sec.) \\
\hline 1 & 0.390398 & $4.9134 \mathrm{E}+03$ & $1.6620 \mathrm{E}-01$ & 2.5614897 \\
\hline 2 & 0.395971 & $4.8105 \mathrm{E}+03$ & $1.6155 \mathrm{E}-01$ & 2.5254356 \\
\hline 3 & 0.702164 & $2.9950 \mathrm{E}+03$ & $5.1376 \mathrm{E}-02$ & 1.4241692 \\
\hline 4 & 1.212025 & $4.1022 \mathrm{E}+01$ & $1.7243 \mathrm{E}-02$ & 0.8250652 \\
\hline 5 & 1.371102 & $3.7299 \mathrm{E}+03$ & $1.3474 \mathrm{E}-02$ & 0.7293403 \\
\hline 6 & 1.392231 & $2.2671 \mathrm{E}+02$ & $1.3068 \mathrm{E}-02$ & 0.7182714 \\
\hline
\end{tabular}


In-place Analysis of Offshore Jacket Platform for Different Wave Directions

Table 4: Base Shear and Overturning Moment Coefficients

\begin{tabular}{|l|l|l|l|l|}
\hline \multicolumn{5}{|c|}{ Base Shear and Overturning Moment Coefficients } \\
\hline Mode & Shear(X) & Shear(Y) & Moment(X) & Moment(Y) \\
\hline & KN & KN & KN-M & KN-M \\
\hline 1 & -877.591 & -254.658 & 3661.055 & -12691.771 \\
\hline 2 & 263.845 & -897.45 & 12642.383 & 3718.422 \\
\hline 3 & -155.224 & -236.168 & -2197.772 & 1383.805 \\
\hline 4 & -201.775 & -0.639 & -8.461 & 10210.758 \\
\hline 5 & -591.686 & -5578.299 & -291206.701 & 30370.011 \\
\hline 6 & 1334.022 & -177.742 & -9589.234 & -68950.095 \\
\hline
\end{tabular}

Table 5: Maximum Deflections for Modes

\begin{tabular}{|c|c|c|c|c|c|c|}
\hline \multicolumn{9}{|c|}{ Maximum Deflections for Modes } \\
\hline Mode & X-Direction & & Y-Direction & & Z-Direction & \\
\hline & Defl. (cm) & Joint & Defl. (cm) & Joint & Defl. (cm) & Joint \\
\hline 1 & 2.54 & $903 \mathrm{~L}$ & 0.833 & $901 \mathrm{~L}$ & -0.265 & $904 \mathrm{~L}$ \\
\hline 2 & -0.893 & $91 \mathrm{ED}$ & 2.54 & $901 \mathrm{~L}$ & 0.498 & $91 \mathrm{ED}$ \\
\hline 3 & 2.54 & $91 \mathrm{ED}$ & 1.759 & $91 \mathrm{ED}$ & 0.147 & $91 \mathrm{ED}$ \\
\hline 4 & 2.54 & 112 & 0.005 & $503 \mathrm{~L}$ & -0.135 & 112 \\
\hline 5 & -1.309 & 112 & 2.54 & $403 \mathrm{~L}$ & -0.964 & $91 \mathrm{ED}$ \\
\hline 6 & 2.54 & 112 & 0.079 & 404L & -0.127 & 112 \\
\hline
\end{tabular}

Table 6: Maximum Moment and Shear

\begin{tabular}{|c|c|c|c|c|c|c|c|c|c|}
\hline \multicolumn{10}{|c|}{ Maximum Moment and Shear } \\
\hline $\begin{array}{c}\text { Wave } \\
\text { Height }\end{array}$ & $\begin{array}{c}\text { Wave } \\
\text { Direction }\end{array}$ & Max. Moment & Max. Shear & Phase & Time & $\begin{array}{c}\text { Min. } \\
\text { Moment }\end{array}$ & Min. Shear & Phase & Time \\
\hline $\mathrm{m}$ & Degree & KN-m & KN & Degree & sec. & KN-M & KN & Degree & sec. \\
\hline 6.1 & 0 & 42097.41 & 723.86 & 0 & 0 & -17726.96 & -341.13 & 144 & 5.2 \\
\hline 6.1 & 45 & 41676.05 & 709.86 & 0 & 0 & -17764.08 & -342.1 & 144 & 5.2 \\
\hline 6.1 & 90 & 42024.07 & 712.46 & 0 & 0 & -17727.5 & -340.58 & 144 & 5.2 \\
\hline 12.19 & 0 & 152374.67 & 2414.12 & 18 & 0.65 & -33333.32 & 662.71 & 144 & 5.2 \\
\hline 12.19 & 45 & 150494.94 & 2344.16 & 18 & 0.65 & -33257.54 & -661.99 & 144 & 5.2 \\
\hline 12.19 & 90 & 151875.28 & 2348.19 & 18 & 0.65 & -33370.26 & -663.24 & 144 & 5.2 \\
\hline
\end{tabular}

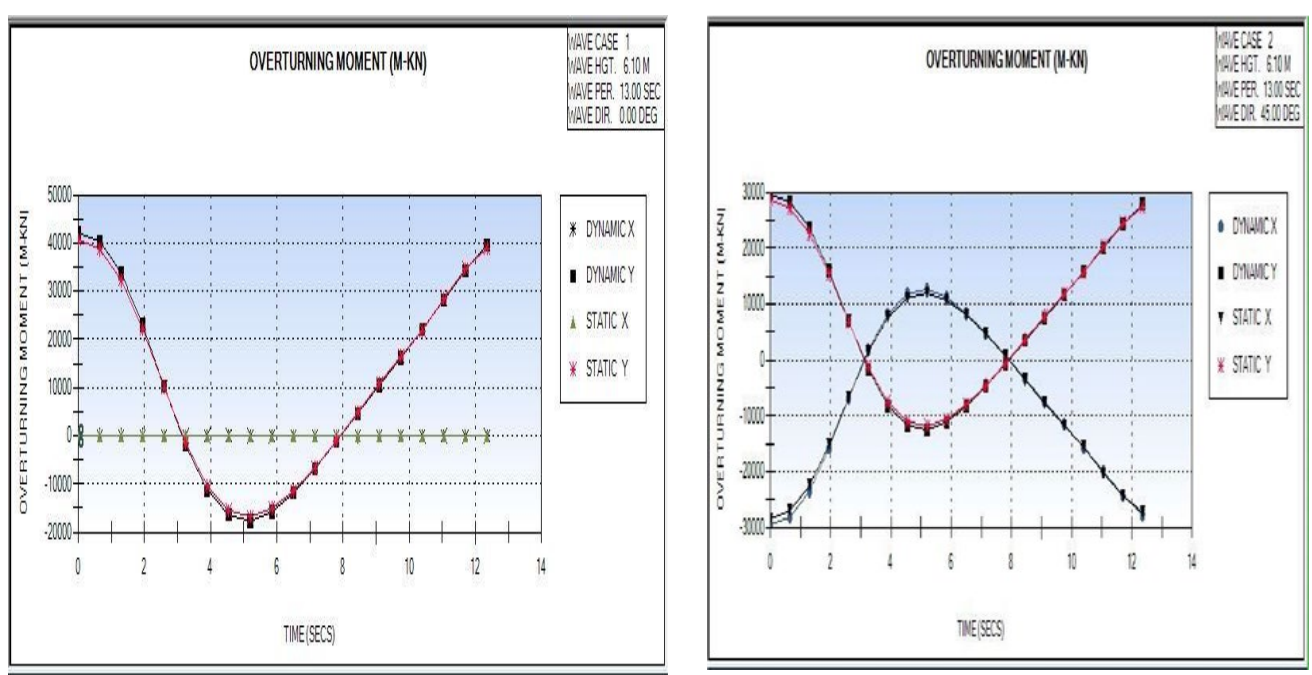

Figure 4: Overturning Moment from different wave theory. 

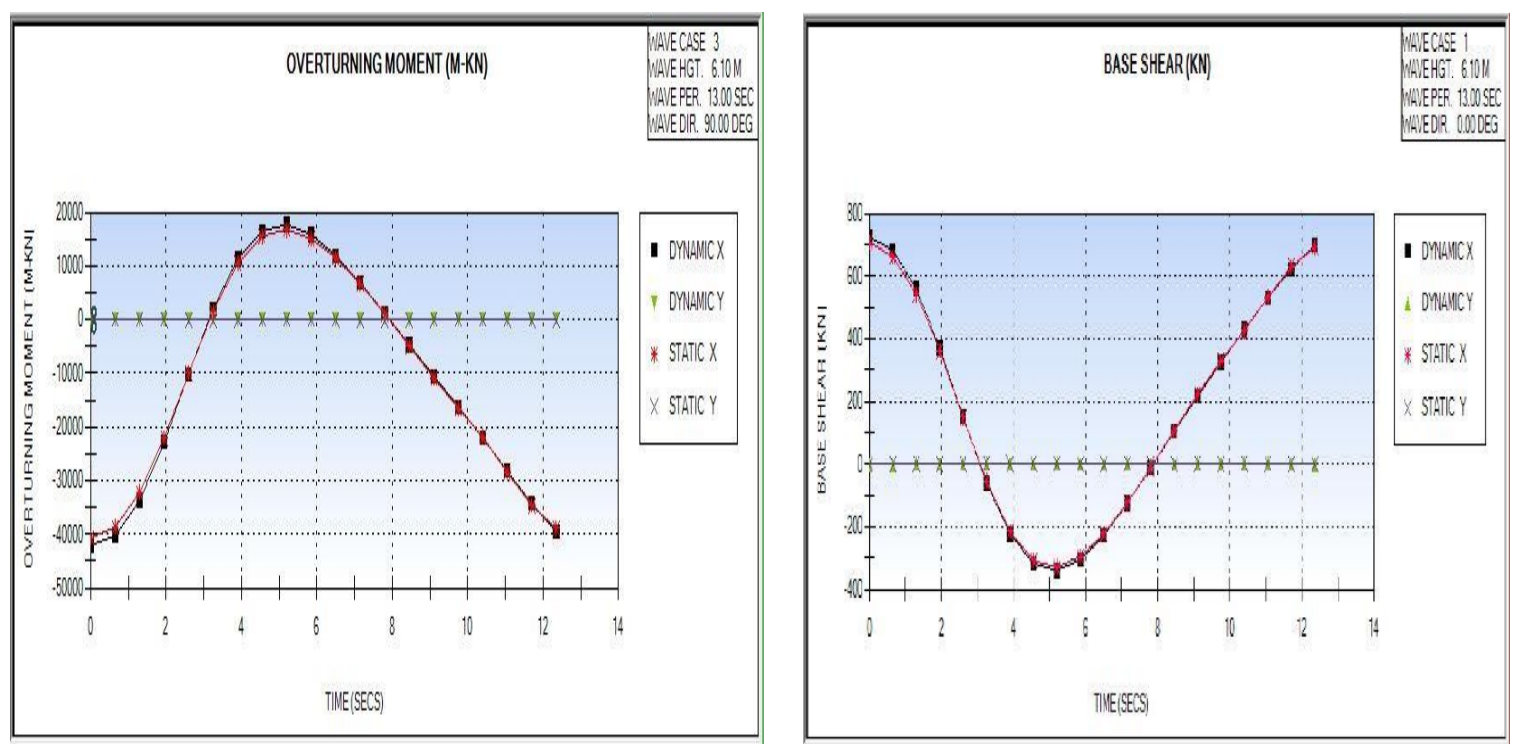

Figure 5: Overturning Moment and Base shear from different wave theory.

\subsection{RANDOM WAVE APPROACH}

Table 7: Surface Profile Statics

\begin{tabular}{|c|c|c|c|c|c|c|c|c|}
\hline \multirow{2}{*}{ Seed NO. } & \multicolumn{2}{|c|}{ Maximum Wave } & \multicolumn{2}{c|}{ Max. Crest } & \multicolumn{2}{c|}{ Min. Trough } & Zero Up crossing Period & Kurtosis \\
\cline { 2 - 10 } & Height & Time & Height & Time & Height & Time & & \\
\hline & $(\mathrm{m})$ & $(\mathrm{sec})$ & $(\mathrm{m})$ & $(\mathrm{sec})$ & $(\mathrm{m})$ & $(\mathrm{sec})$. & $(\mathrm{sec})$ & \\
\hline 1 & 13.78 & 713 & 7.43 & 134.5 & -6.74 & 715.5 & 8.76 & 3.1365 \\
\hline 2 & 13.58 & 714 & 7.33 & 135 & -7.19 & 778 & 8.82 & 2.129 \\
\hline 3 & 13.79 & 715.25 & 7.13 & 712.5 & -7.11 & 379.5 & 9.09 & 3.095 \\
\hline 4 & 13.88 & 716 & 6.99 & 421.5 & -7.19 & 713 & 8.82 & 3.09 \\
\hline 5 & 13.38 & 605.25 & 7.42 & 380.5 & -6.68 & 777.5 & 8.57 & 3.08 \\
\hline
\end{tabular}

Table 8: Overturning Moment and Base Shear

\begin{tabular}{|c|c|c|c|c|c|c|c|c|c|c|c|c|}
\hline \multirow{2}{*}{ 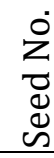 } & \multicolumn{3}{|c|}{ Maximum } & \multicolumn{3}{|c|}{ Minimum } & \multicolumn{3}{|c|}{ Maximum } & \multicolumn{3}{|c|}{ Minimum } \\
\hline & OTM & Time & Phase & OTM & Time & $\begin{array}{c}\text { Phas } \\
\text { e }\end{array}$ & BS & Time & Phase & BS & Time & $\begin{array}{c}\text { Phas } \\
\text { e }\end{array}$ \\
\hline & $\mathrm{kN}-\mathrm{m}$ & (sec.) & (deg) & $\mathrm{kN}-\mathrm{m}$ & (sec.) & (deg) & $(\mathrm{KN})$ & (sec.) & (deg) & $(\mathrm{kN})$ & (sec.) & (deg) \\
\hline 1 & $\begin{array}{c}188042.3 \\
3\end{array}$ & 377.6 & $\begin{array}{c}113.2 \\
5\end{array}$ & $\begin{array}{c}- \\
113003.5 \\
4\end{array}$ & $\begin{array}{c}715.2 \\
9\end{array}$ & $\begin{array}{c}214 . \\
5\end{array}$ & $\begin{array}{c}2670.8 \\
1\end{array}$ & 377.65 & $\begin{array}{c}113.2 \\
5\end{array}$ & $\begin{array}{c}- \\
1648.1 \\
9 \\
\end{array}$ & $\begin{array}{c}715.2 \\
9\end{array}$ & $\begin{array}{c}214 . \\
5\end{array}$ \\
\hline 2 & $\begin{array}{c}206924.5 \\
8\end{array}$ & $\begin{array}{c}715.79 \\
8\end{array}$ & $\begin{array}{c}214.6 \\
5\end{array}$ & $\begin{array}{c}- \\
101634.7 \\
4\end{array}$ & $\begin{array}{c}418.1 \\
7\end{array}$ & $\begin{array}{c}125 . \\
4\end{array}$ & $\begin{array}{c}3027.0 \\
9\end{array}$ & $\begin{array}{c}715.79 \\
8\end{array}$ & $\begin{array}{c}214.6 \\
5\end{array}$ & $\begin{array}{c}- \\
1487.7 \\
9\end{array}$ & $\begin{array}{c}418.1 \\
7\end{array}$ & $\begin{array}{c}125 . \\
4\end{array}$ \\
\hline 3 & $\begin{array}{c}231149.7 \\
2\end{array}$ & 779.82 & $\begin{array}{c}233.8 \\
5\end{array}$ & $\begin{array}{c}- \\
117878.1 \\
2\end{array}$ & $\begin{array}{c}899.3 \\
7\end{array}$ & $\begin{array}{c}269 . \\
7\end{array}$ & $\begin{array}{c}3157.9 \\
2\end{array}$ & 779.82 & $\begin{array}{c}233.8 \\
5\end{array}$ & -1414.3 & $\begin{array}{c}899.3 \\
7\end{array}$ & $\begin{array}{c}269 . \\
7\end{array}$ \\
\hline 4 & $\begin{array}{c}204852.2 \\
3\end{array}$ & 582.24 & 174.6 & $\begin{array}{c}- \\
103802.6 \\
1\end{array}$ & $\begin{array}{c}780.3 \\
2\end{array}$ & 234 & $\begin{array}{c}2854.7 \\
7\end{array}$ & 582.24 & 174.6 & $\begin{array}{c}- \\
1516.2 \\
1 \\
\end{array}$ & $\begin{array}{c}780.3 \\
2\end{array}$ & 234 \\
\hline 5 & $\begin{array}{c}204803.0 \\
5\end{array}$ & 782.82 & $\begin{array}{c}234.7 \\
5\end{array}$ & $\begin{array}{c}- \\
106541.9 \\
6\end{array}$ & $\begin{array}{c}132.0 \\
5\end{array}$ & 39.6 & $\begin{array}{c}2885.0 \\
3\end{array}$ & 782.82 & $\begin{array}{c}234.7 \\
5\end{array}$ & $\begin{array}{c}- \\
1453.4 \\
6\end{array}$ & $\begin{array}{c}132.0 \\
5\end{array}$ & 39.6 \\
\hline
\end{tabular}




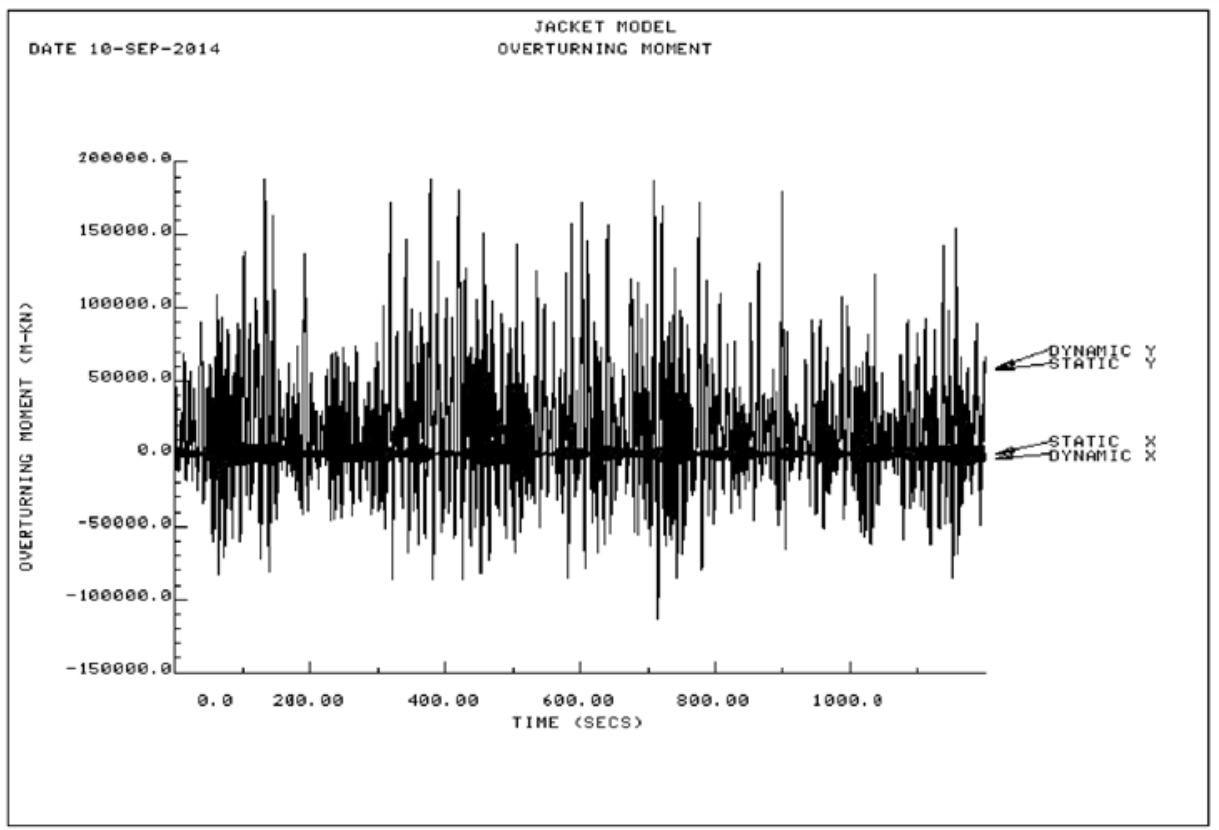

Figure 7: Overturning Moment

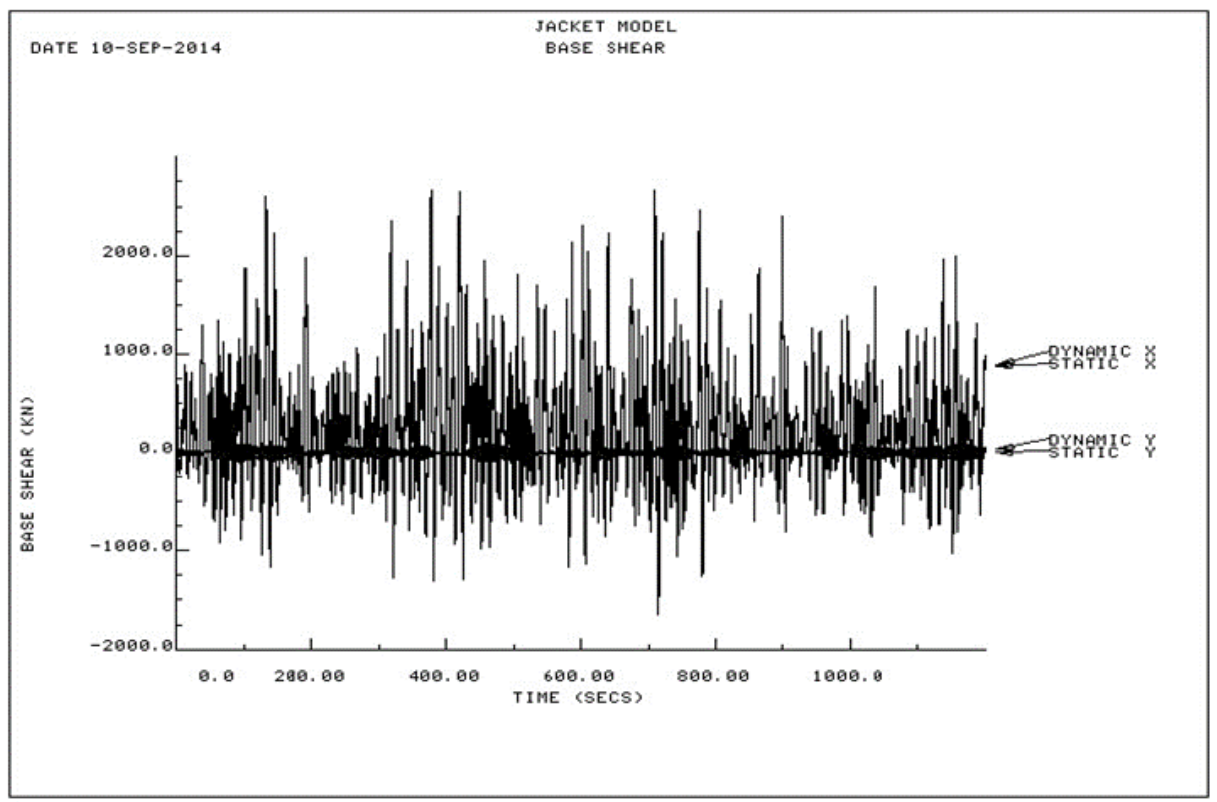

Figure 8: Base Shear

\section{CONCLUSIONS}

The Base Shear and Overturning Moment increases with increase in wave height. The maximum overturning moment and Base Shear are in load case S090.

The Base Shear and Overturning moment in Stoke's 5th order theory is more under each load cases. Stokes' 5th order wave provides five components for the wave kinematics. Each component is generally an order of magnitude smaller than the previous one in succession. The wave profiles from the five components combine to provide a steeper crest and shallower trough.

The dynamic characteristics (mode shapes and frequencies) of the structure are generated with reduced structural stiffness matrix and consistent mass approach in SACS. When dealing with very large structures the technique of mass condensation may be used. A set of master (retained) degrees of freedom are selected at each 
horizontal elevation on the main legs to extract the Eigen values(periods) and Eigen vectors (mode shapes), which includes all stiffness and mass properties related to the reduced degrees of freedom tabulated.

After the modes are extracted using the master degrees of freedom, they are expanded to include the full 6 degrees of freedom for all joints in the structure.

A consistent mass approach is considered since it is more desirable for structures immersed in the fluid. The added mass is generated automatically by SACS and depends on the size, orientation and proximity of the member to the free surface

The eigenvalue parameter and mass participation factor for the first 15 mode shapes are tabulated in Table 4.2 and 4.6 respectively as the results from the dynamic analysis. The first Fundamental period of the structures is 2.56 with Frequency of $0.39 \mathrm{cps}$.

The Structure vibrates predominantly with $60 \%$ mass participation in $\mathrm{X}$ and $\mathrm{Y}$ direction. There is no significant torsion in first six mode.in seventh mode there is significant torsion in the structure. The structure reaches $90 \%$ mass Participation in fifth mode.

Nature of Overturning moment and Base Shear are different for different direction.

The Overturning moment and Base Shear increase with increase in Wave height.

For wave angle $45 \mathrm{deg}$. Jacket experiences significant moment in both $\mathrm{X}$ and $\mathrm{Y}$ directions.

For same loading condition in $0 \mathrm{deg}$. and $90 \mathrm{deg}$. The Overturning Moment is different.

The irregular time space investigation is finished utilizing the full three-measurement SACS model. The wave reaction module of SACS is equipped for performing dynamic auxiliary reaction. Examination coming about because of arbitrary wave stacking. The info identified with the time venturing is required and the wave vitality range to be utilized to produce the irregular ocean surface profile and the Frequency band to be utilized to create the wave segments. The vitality range is separated into groups of the width indicated and the region in each band determined. This vitality is then changed over into a vaporous wave and all the waves from the groups are superimposed with an irregular Phase distinction between the segments. So as to make diverse ocean surface profiles an irregular number of seeds are utilized to give distinctive stage edges to them segments of the range for every ocean surface produced. In this analysis 5 different sea surface profiles of 1200 seconds duration was generated and Responses calculated for each profile at 0.5 second intervals.

From each of the 20 simulations the largest peak responses of dynamic base Shear force and dynamic overturning moment were peaked. The maximum Base Shear and

Overturning moment was in Random Seed 3 with magnitude of $3157.92 \mathrm{kN}$ and $231149.72 \mathrm{kN}-\mathrm{m}$ at $779.82 \mathrm{sec}$ at Phase of $233.82 \mathrm{deg}$.

Maximum Wave height, was $13.88 \mathrm{~m}$ at Random Seed 4 at time $716 \mathrm{sec}$.

\section{SOURCES OF FUNDING}

This research received no specific grant from any funding agency in the public, commercial, or not-for-profit sectors.

\section{CONFLICT OF INTEREST}

The author have declared that no competing interests exist.

\section{ACKNOWLEDGMENT}

None.

\section{REFERENCES}

[1] American Petroleum institute (2000). Recommended Practice for Planning, Designing and constructing Fixed Offshore Platforms -Working Stress Design .21st ed. Washington API.

[2] C. H. Jo. K.S.Kim ,S.H Lee Parametric Study on offshore jacket Launching Dawson T.H (1983). Offshore Structural Engineering Englewood Cliffs: Prentice Hall. 
[3] D.V. Reddy, A. S. J Swamidas, S. Reddy, Offshore Structures, vol.1 by D.V. Reddy and M. Arockiasamy Gaithwaite.J.(1981). The Marine Environment and Structural Design. New York:Van Nostrand Reinhold Company.

[4] Gerwick, B.C,1986. Construction Of offshore structures. John Wiley and Sons,inc, KAIST-a,1985. Development of Design technology of Offshore Platforms for Offshore Oil Production. Glinter clauss, Eike Lehmann \& Carsten Ostergaard, offshore structures vol .1

[5] J.L. Alamilla, D. Campos, C. Ortega, a. Soriano, J.L. Morales, Optimum selection of design parameters for transportation of offshore structures F.H..H. A Quadvlieg A.B.Aalbers ,R.P Dallinga,C.E.J. Leenars Voyage

[6] Acceleration climate: A New method to come to Realistic Design Values for Ship Motions Based on the Full Motion Climate for a Particular Transport

[7] Knight, R.M. and Daniel, J.J.S. (1993). World Trends in Major Offshore Structures 1970-1999. Proceeding of the 3rd International Conference on Offshore 93: Installation of Major Offshore Structures and Equipments. February 17-18. london: IMarE/RINA,17-23.

[8] S. Chakrabarti (Ed.) Handbook of Offshore Engineering

[9] Engineering dynamics, SACS manual,2004 